\title{
eCOti
DiAno
}

Revista Mídia e Cotidiano

ISSN: 2178-602X

Artigo Seção Temática

Volume 15, Número 2, maio/ago. de 2021

Submetido em: 22/02/2021

Aprovado em: 18/04/2021

\section{Imagens de um devir-animal: entre literatura e ilustração no conto "Conversa de bois", de Guimarães Rosa}

\section{Images of a becoming-animal: between literature and illustration in the tale "Conversa de bois" of Guimarães Rosa}

\section{Imágenes de un devenir-animal: entre literatura e ilustración en el cuento “Conversa de bois”, de Guimarães Rosa}

\author{
Gabriela Pereira de FREITAS ${ }^{1}$ \\ Rhaysa Novakoski CARVALHO ${ }^{2}$
}

\begin{abstract}
Resumo
Tendo em vista o questionamento "como o devir estabelece a relação híbrida entre ilustração e palavra no conto 'Conversa de bois', de Guimarães Rosa", este artigo levanta reflexões sobre e a partir de certo indiscernimento entre imagens sensíveis e visíveis, que tanto emanam mentalmente do texto quanto o acompanham como ilustração literária visível. Com plano de fundo tecido por meio dos conceitos de Krauss e Bellour sobre campo expandido e relações híbridas entre imagem e literatura, aqui se desencadeia uma caminhada por algumas apreensões sobre o tema, em um devaneio que evoca e relaciona imagens para entender um devir-palavra e um devir-escritor-feiticeiro submersos em uma aura de mistério. O imaginário de feiticeiro e as simbologias do boi, são, também, chaves interpretativas que relacionam o conto e o livro rosiano como objeto aos conceitos de feitiçaria e devir-animal, de Deleuze e Guattari.
\end{abstract}

Palavras-chave: Devir. Ilustração. Imagem. Guimarães Rosa.

\begin{abstract}
Having in mind the question "how does becoming establish hybrid relationships between illustration and words in the tale 'Conversa de bois', by Guimarães Rosa", this article raises reflections on and from a certain indiscernment between visible and sensitive

\footnotetext{
${ }^{1}$ Fotógrafa e professora adjunta da Faculdade de Comunicação da Universidade de Brasília (UnB), com doutorado em Comunicação pela UnB (2014) e período sanduíche na Sorbonne Université. Está realizando o pós-doutorado na State University of New York (2021). Publicou o livro "Estética em fluxo. Experiência e devir entre artemídia e comunicação" em 2018, pela editora Appris. E-mail: gabriela.freitas@gmail.com. ORCID: 0000-0002-6195-3871

2 Mestranda pelo Programa de Pós-Graduação em Comunicação da Universidade de Brasília (UnB), na linha de Imagem, Estética e Cultura Contemporânea. Jornalista formada pela UFMA. Pesquisadora do Siruiz (Grupo de Estudos em Comunicação e Produção Literária). E-mail: novakoski.rhaysa @ gmail.com. ORCID: 0000-0003-4333-2104.
} 
images, both emanating mentally from the text and accompanying it as literary visible illustration. Based on the background built upon the concepts suggested by Krauss and Bellour on expanded field and hybrid relations between image and literature, we propose reflections which are triggered by some apprehensions on the theme, in a sort of daydream dynamic that evokes and relates images to understand a becoming-word and a becomingwriter-sorcerer. The imaginary on the sorcerer and the ox are also interpretative keys that relate the Rosian tale and the book itself as an object to the concepts of witchcraft and becoming-animal, by Deleuze and Guattari.

Keywords: Becoming-animal. Illustration. Image. Guimarães Rosa.

\section{Resumen}

Guiándose por la pregunta "¿cómo el devenir establece la relación híbrida entre ilustración y palabra en el cuento 'Conversa de bois' de Guimarães Rosa?", este artículo plantea reflexiones sobre y a partir del no discernimiento entre imágenes sensibles y visibles, que tanto emanan mentalmente del texto cuanto lo acompañan como ilustración literaria visible. Basado en los conceptos de Krauss y Bellour sobre campo expandido y relaciones híbridas entre imagen y literatura, aquí se desarrolla una caminada por algunos pensamientos sobre el tema, en un devaneo que evoca y relaciona imágenes para comprender un devenir-palabra y un devenir-escritor-hechicero sumergidos en aura de misterio. Así, el imaginario de hechicero y del buey son, también, claves interpretativas que relacionan el cuento y el libro como objeto a los conceptos de hechicería y deveniranimal, de Deleuze y Guattari.

Palabras clave: Devenir. Ilustración. Imagen. Guimarães Rosa.

\section{Potência híbrida, vontade de mistério}

No ponto de contato entre a filosofia do devir ${ }^{3}$, em Deleuze e Guattari, a literatura e a ilustração, em João Guimarães Rosa, capta-se o surgimento de uma linha de fuga que, por sua vez, desencadeia uma potência híbrida a ser explorada no decorrer destas páginas. Inserindo-se no contexto dos campos híbridos e expandidos - espaços tão caros a Rosa, apesar do foco muitas vezes mais óbvio sobre seu texto - este artigo se propõe a pensar como o devir estabelece relações entre palavra e ilustração a partir do conto "Conversa de bois" e suas imagens — sejam elas místicas, mentais ou visíveis.

\footnotetext{
3 "Devir é, a partir das formas que se tem, do sujeito que se é, dos órgãos que se possui ou das funções que se preenche, extrair partículas, entre as quais instauramos relações de movimento e repouso, de velocidade e lentidão, as mais próximas daquilo que estamos em vias de nos tornarmos, e através das quais nos tornamos. É nesse sentido que o devir é o processo do desejo" (DELEUZE; GUATTARI, 1997, p.64).
} 
Dessa maneira, tendo como plano de fundo conceitos de Krauss e Bellour, estabelecemos diálogos entre o objeto desta reflexão e o texto "Devir-intenso, deviranimal, devir-imperceptível”, em Mil Platôs (1997), para esboçar um emaranhado de pensamentos que cruzam um devir-boi identificado no conto de Rosa, com perspectivas imagéticas sobre o boi, o feiticeiro (deleuziano) e alguns dos mistérios que povoam o imaginário em torno dessas figuras. Forma-se, assim, um campo de indiscernimento entre imagens visíveis e mentais que surgem com e a partir do texto e se manifestam no objeto híbrido que é o livro rosiano.

Prontamente destacamos que, para o escritor, sua prosa estava, também, relacionada ao cuidado com as imagens, com foco, neste artigo, para as ilustrações. A percepção do livro enquanto objeto de arte demonstrava uma compreensão que Guimarães Rosa tinha deste ocupando um espaço, em alguns casos quase como uma escultura ou instalação, como ocorre em Corpo de baile, conforme será visto a seguir. A partir dessas observações é que recorremos aos pensamentos acerca das transformações apontadas por Rosalind Krauss (2014) inicialmente no campo da escultura, que propõe a noção de campo ampliado, ou campo expandido.

A autora ressalta como a possibilidade dos campos ampliados, no contexto de ebulição da arte contemporânea, se constitui a partir de uma concepção complexa na qual as diversas linguagens se encontram em relação, tomando parte num conjunto cultural em que deixam de se distinguir a partir das características restritas à linguagem de origem, como gostaria de compreender nossa mentalidade historicista. Para Krauss, tal possibilidade é resultado de um contexto histórico que "pressupõe a aceitação de rupturas definitivas e a possibilidade de olhar para o processo histórico de um ponto de vista da estrutura lógica” (KRAUSS, 2014, p.137). O campo ampliado, estabelece-se, portanto, na relação mesma, a partir de um conjunto artístico ou cultural híbrido que se classificaria entre linguagens, ou seja, não seria determinado por uma ou outra especificamente.

Como mencionado acima, essa concepção era cara a Rosa na organização de cada um de seus livros. A maestria no uso da linguagem escrita levou uma legião de estudiosos a se debruçar sobre seus textos e ignorar cadernos de rascunhos, ilustrações e 
planejamentos de seus livros-objeto ${ }^{4}$. Esses recursos são apontados como chaves de sentido em estudos como os de Rowland (2011) sobre a forma do livro rosiano, ou sobre a dimensão de "artefato" dessas publicações, como indica a autora em alguns momentos. Entre materiais de arquivo e elementos paratextuais (índices, capas, orelhas etc.), Rowland indica as ilustrações como peças importantes na compreensão da obra do autor, quando pensada enquanto objeto híbrido e complexo para além do texto.

\section{Figura 1 - Capa e contracapa de Manuelzão e Miguilim, Corpo de baile}
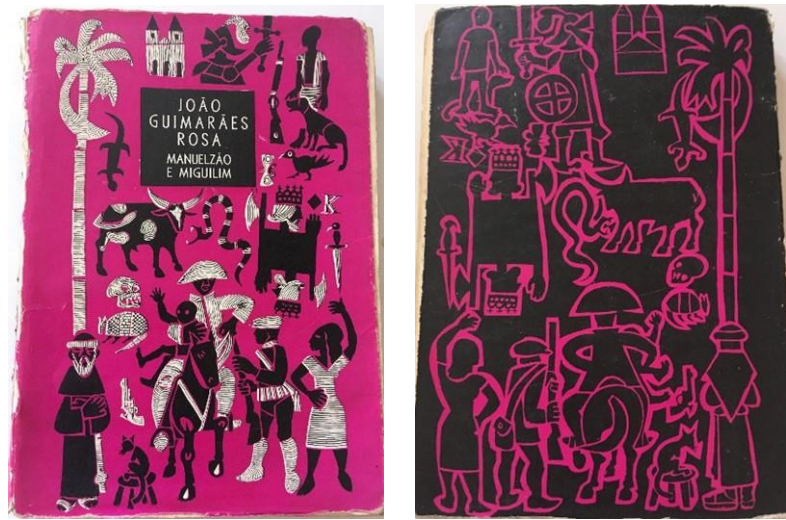

Fonte: ROSA, 1972.

Exemplo da força no cuidado editorial empregado por Rosa e da construção material dos sentidos que envolvem suas publicações são as terceiras edições ${ }^{5}$ de Corpo de baile (1962), em que as ilustrações são dispostas na capa e contracapa de maneira a sugerir um objeto tridimensional, semelhante a uma escultura: nas capas, personagens, animais e objetos são vistos frontalmente, voltados para o leitor-observador; nas contracapas, figuram as mesmas imagens, mas visualizadas a partir do olhar de quem assiste a uma cena atrás do palco (Figura 1) (ROWLAND, 2011).

Já em Sagarana (1956; 1958; 1977), o livro no qual está publicado o conto que guia este estudo, as ilustrações de capa e miolo foram traçadas pelo gravurista Poty

\footnotetext{
${ }^{4}$ Livro-objeto pode ser entendido como a publicação que extrapola as convenções tradicionais de livro, subvertendo sobretudo seu projeto gráfico e embaçando as fronteiras entre texto e suporte, por meio, dentre outros elementos, da apresentação visual. Os livros de Guimarães Rosa possuem características pontuais que poderiam ser encaixadas nessa dinâmica, mas de maneira geral não o são. Apesar disso, tomaremos licença para usar essa expressão devido à preocupação do autor com o processo de edição, construção material e ilustração.

${ }^{5}$ Corpo de baile foi dividido em três livros a partir da terceira edição, de 1962.
} 


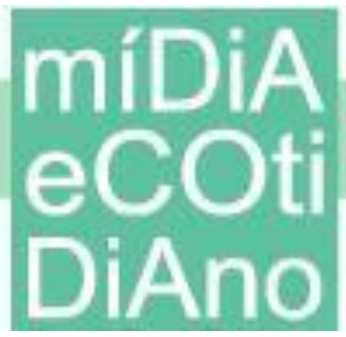

Lazzarotto $^{6}$, sendo solicitadas (e até descritas), avaliadas e selecionadas por Rosa. Desde a primeira edição lançada pela editora José Olympio, a obra passou por diversos ajustes gráficos e textuais, decorrentes de uma certa obsessão de Rosa em realizar modificações e correções (ROWLAND, 2011).

O visual mais conhecido foi elaborado por Poty em 1956, mas somente a partir da quinta edição do livro "definitivo-para-sempre" (sem mais alterações textuais), de 1958, é que as ilustrações passaram a acompanhar o texto em seu interior. Grande parte dos desenhos são apresentados em forma circular, como emblemas (NUNES, 2015). Após a morte do escritor, as ilustrações passaram por pequenas mudanças nas sucessivas edições a partir de 1970. Segundo Nunes (2015), os motivos para as alterações não são conhecidos, e, mesmo não afetando uma análise no campo temático, elas acabam influenciando a leitura em termos estilísticos. Por conta disso, as ilustrações apresentadas aqui terão duas versões: os traços de 1958 e os da edição de 1977 - já que não conseguimos acesso à de 1970, mas ambas possuem os mesmos desenhos.

Após a inserção das ilustrações no miolo, Sagarana pode ser definido como um livro ilustrado - de figuras "glosantes" (ROSA, 1975). Em termos gerais, o livro ilustrado é aquele que combina a comunicação verbal e não-verbal para criar uma linguagem distinta, e, por vezes, híbrida (NIKOLAJEVA; SCOTT, 2011). E é tendo em vista o diálogo entre as diferentes expressões entrelaçadas magicamente por Guimarães Rosa que se buscará compreender as imagens animalescas evocadas em "Conversa de bois" a partir do devir. Como auxílio, serão relacionados ao longo do trabalho autores que discutem os estudos animais, a zooliteratura e a ficção animalista na obra rosiana, como Neves (2020) e Pereira (2020), por exemplo.

De acordo com Pereira, nos estudos animais a expressão devir-animal pode ser usada como forma de tradução de um certo "estreitamento das fronteiras entre humano/humano, humano/inumano, inumano/inumano, ou pelo menos sugere rever as

\footnotetext{
${ }^{6}$ Por falta de acesso aos originais, não há consenso sobre qual seria a técnica de criação e reprodução das ilustrações de Poty para Sagarana. De acordo com Nunes (2015), todas as edições possuem impressões realizadas a partir de matrizes em alto relevo, especulação comprovada pelo leve afundamento das áreas impressas. O autor conta que, para as edições a partir de 1970, a hipótese mais forte é o uso da xilogravura (entalhe em madeira) combinado com detalhes feitos posteriormente em bico-de-pena, técnica favorita de Poty e, por conta das características do traço, provavelmente utilizada na primeira versão das ilustrações, em 1958.
} 


\section{míDiA

posturas assumidas diante do outro" (PEREIRA, 2020, p. 32). No texto de Rosa lê-se o boi vivenciado como um ser pensante, envolto na aura mágica das fábulas ou contos de fadas. O narrador avisa sobre o caráter da história "re-recontada" ao dizer, logo no início, que "já houve um tempo em que eles conversavam, pois bem comprovado nos livros das fadas carochas" (ROSA, 2016, p. 290). O leitor é convidado a ouvir um "caso acontecido", que se desenrola em meio às conversas de oito bois: Buscapé, Namorado, Capitão, Brabagato, Dançador, Brilhante, Realejo e Canindé. Em certo momento, os pensamentos dos animais se chocam com os de Tiãozinho, o menino que conduz o carro de boi enquanto sofre pela morte do pai - cujo corpo é levado na carroceria - e com os maus tratos de Agenor Soronho, carreiro cruel e insensível.

Em certo momento, as percepções animalescas capturam o guia em um deviranimal, na mesma medida em que os bois se deixam capturar pelo desejo homicida do menino. O devir redireciona vontades e desloca Tiãozinho para um não lugar, um entre, nem boi nem menino. Esse mesmo jogo imagético e interpretativo pode ser montado e desmontado em vários níveis narrativos tanto dentro do conto quanto entre texto e ilustrações, como também entre as imagens/sentidos cooptados em ambas as formas de expressão (palavra-literatura e ilustração). O devir-boi do menino, dessa maneira, corresponde a um devir-ilustra-palavra, como veremos adiante, constituindo um campo ampliado fértil para as diferentes relações entre linguagens.

Nesse sentido, para Raymond Bellour, o entre, que está no título de seus livros, dá ênfase mesmo à passagem de uma linguagem a outra. $\mathrm{O}$ primeiro volume de EntreImagens é dedicado à fotografia, cinema e vídeo. $\mathrm{O}$ autor se detém sobre as linguagens tipicamente imagéticas. No entanto, sua reflexão sempre leva à imagem primordial, aquela da imaginação e do imaginário e que tanto permeia a literatura, por exemplo. Bellour analisa inúmeros filmes, vídeos e imagens que têm como referência textos literários, mostrando sua potência imagética.

Aparecerá, algum dia, talvez, que o deslizamento do cinema em direção ao vídeo é comparável àquele que se deu com a poesia na passagem dos versos alexandrinos aos versos livres. Que um pensamento sobre o 
destino literário da língua surgiu assim como hoje se dá o pensamento sobre a imagem (BELLOUR, 1990, p.26) ${ }^{7}$.

A concepção imagética da literatura é tão importante para o estudioso, que seu segundo volume de Entre-Imagens é dedicado exclusivamente à relação entre palavra e imagem. O autor cita o argentino Jorge Luís Borges, e sua capacidade de se precipitar numa vertigem de metamorfoses, para comparar o escritor a um espectador, prisioneiro de um dispositivo que não o permite deixar de fazer seu próprio cinema interno enquanto escreve.

Seu próprio truque de mágica e sua invenção de escritor, aqui, são também a sublinhar, de forma às vezes mítica, lúdica e histórica, a emergência de um dispositivo global no interior do qual palavras e imagens, literatura e cinema, fazem um intercâmbio de suas propriedades. Fazem-no a partir de uma mesma postura que coloca o homem no espelho, ciente de sua imagem - com um excesso que promove a partilha do desejo de viver e morrer nela (BELLOUR, 1999, p. 323$)^{8}$.

É nessa dinâmica da relação híbrida entre imagem e palavra — principalmente na formação das imagens mentais que, como diria Bergson (2010), povoam nosso cinetoscópio interior - que acreditamos desenrolar-se um devir, tanto quando atuamos como escritores, cineastas, pintores e fotógrafos quanto como espectadores. Mais especificamente, acreditamos que os movimentos de associação e aliança entre imagens e palavras, assim como também entre outras linguagens, podem ser compreendidos por um processo em devir, na constituição de um campo expandido. Pois só pelo devir é que se pode abarcar o estado que se é, sendo, ou seja, que se estabelece na relação; no entre linguagens, e não em um ou outro estado.

De acordo com Nikolajeva e Scott (2011), no livro ilustrado a relação entre palavra e imagem pode ser estabelecida de diversas maneiras, sugerindo, sobretudo, complementaridade (no caso de significarem distintamente) e simetria (no caso de expressarem os mesmos sentidos). A primeira categoria parece ser mais próxima do que ocorre em Sagarana, principalmente quando se percebe que o leitor deve encontrar os

\footnotetext{
7 Tradução nossa.

8 Tradução nossa.
} 


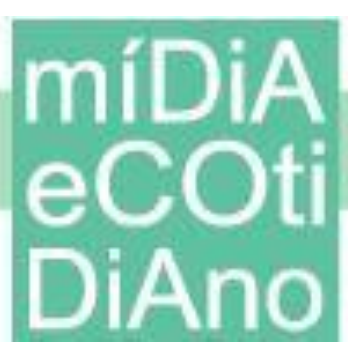

significados específicos das ilustrações, "se possível, no meio do livro, emergindo no material textual: são figuras que sugerem aspectos enigmáticos, cujas respostas só poderão ser encontradas no interior do livro" (NUNES, 2015, p. 548), ou seja, no contato entre as linguagens, como visto acima.

A proposta de diálogo entre palavra e ilustração desenvolvida aqui, com ênfase na imagem visível, é um caminho pouco usual nos estudos sobre a literatura rosiana. Para justificar essa intuição interpretativa, buscamos em Mitchell (2015) o que ele chama de virada pictórica - movimento mais ou menos recente pelo qual se propõe que a imagem deve ser compreendida e pensada a partir de sua própria consistência. Assim, o autor ressalta que ela mesma é capaz de constituir uma ênfase no campo social do visual, quando afirma que este não é apenas "um produto secundário da realidade social, mas um elemento que a constitui ativamente. A visão é tão importante quanto a linguagem na mediação de relações sociais sem ser, no entanto, redutível à linguagem, ao 'signo' ou ao discurso" (MITCHELL, 2015, p. 186).

As ilustrações de Sagarana inserem-se no contexto do tratamento literário das imagens, como ressalta Mitchell, e, diante disso, acabam por celebrar sua personalidade misteriosa, pois já se encontram mediadas por outra linguagem (MITCHELL, 2015). Quando o autor se refere a uma personalidade das imagens, o faz no sentido de buscar uma subjetividade não apenas de seus autores e receptores, mas uma subjetividade própria da imagem, indagando não o que se quer delas, mas procurando desvendar seu próprio desejo: o que querem as imagens?

Podemos dizer que, no caso das ilustrações de "Conversa de Bois", há justamente uma complementaridade entre imagem e texto no sentido de que as palavras não querem explicar as ilustrações, mas construir um diálogo, além de, em sua dimensão mística, se revelarem como criadoras de uma realidade própria, evocando a animalidade do boi como mediação da experiência literária em suas múltiplas manifestações. A imagem não quer ser decodificada pelo texto, mas encantar por si só, como propõe Mitchell ao tentar responder à pergunta que dá início ao seu estudo - e encerra o parágrafo anterior: 
Os desejos das imagens podem ser inumanos ou não-humanos, mais bem modelados pelas figuras de animais, máquinas, ciborgues, ou mesmo por imagens ainda mais básicas - aquilo que Erasmus Darwin chamava de "o amor das plantas". Portanto, o que as imagens querem, em última instância, é simplesmente serem perguntadas sobre o que querem, tendo em conta que a resposta pode muito bem ser "nada" (MITCHELL, 2015, p. 187).

É dessa maneira, que, finalizando uma abordagem introdutória, ressaltamos que essa caminhada terá como guia as imagens de "Conversa de bois" e seus desejos, a partir das noções que permeiam o devir. E a dimensão misteriosa, amplamente discutida no projeto literário de Rosa, deve ser explorada não para o seu desvelamento, mas para sua contemplação, expansão e associação rizomática ${ }^{9}$ com novos objetos e pensamentos que atravessam a temática.

\section{Assunto de feiticeiro}

Antes de mergulhar no tema dos bois, é interessante uma passagem pelas feitiçarias e pelos motivos do feiticeiro. Deleuze e Guattari (1997) explicam que o escritor é um feiticeiro porque "escrever é um devir, escrever é atravessado por estranhos devires, que não são devires-escritor, mas devires-rato, devires-inseto, devires-lobo, etc" (DELEUZE, GUATTARI, 1997, p. 17). Para os autores, feiticeiros e devires que outrora se manifestavam em mitos e ritos agora "se exprimem por contos", usando em seu livro os mais diversos "feiticeiros" para apresentar, explicar e discutir devires-animal presentes na literatura. Estas noções encontram correspondência no entendimento de Guimarães Rosa sobre sua escrita, definida por ele como uma tarefa de alquimista, que para "ser feiticeiro da palavra, para estudar a alquimia do sangue do coração humano, é preciso provir do sertão" (LORENZ, 1994, p. 49).

Aqueles que se voltam para sua obra, podem dizer que, certamente, um feiticeiro como Rosa foi atravessado pelos devires mais diversos, tendo, contudo, o sertão como uma espécie de plano de consistência — ou seja, lugar onde podem ser encontradas e

\footnotetext{
${ }^{9}$ Em um rizoma "cada traço não remete necessariamente a um traço linguístico: cadeias semióticas de toda natureza são aí conectadas a modos de codificação muito diversos, cadeias biológicas, políticas, econômicas, etc., colocando em jogo não somente regimes de signos diferentes, mas também estatutos de estados de coisas" (DELEUZE; GUATTARI, 1995).
} 


\section{míDiA

desenroladas aberturas criativas — que dá aos devires que o tomam a possibilidade de tradução por uma miríade de códigos singulares, tendo ainda o animal, ou, no caso deste artigo, o boi, como "assunto de feitiçaria" (DELEUZE, GUATTARI, 1997, p. 25). É a manifestação do que Rosa chama em sua obra de "matéria vertente", designação que se aproxima das metamorfoses vertiginosas descritas por Bellour em relação a Borges e que, também, poderia ser um outro nome para o devir.

Antes de afirmarem que o devir é nele mesmo uma realidade, Deleuze e Guattari falam sobre a dupla ideia de "série-estrutura", dos arquétipos de Jung e dos estudos totêmicos de Lévi-Strauss como intuições que tentavam entender o que chamam de deviranimal, aproximando o mundo da natureza e seus bichos aos sonhos e mitos, como formas de explicar a relação entre os animais, entre animais e homens e entre homens e instituições/organizações.

Tais colocações levantam o questionamento sobre o sonho e a mediunidade enquanto manifestações, explicações ou modos de relação dos devires que capturavam o autor em diversos momentos, desencadeando a criação de imaginários presentes em seus textos e na maneira como o escritor relaciona a palavra às ilustrações que seleciona para os livros. Sobre o processo de escrita de "Conversa de bois", por exemplo, Rosa conta, em correspondência com o amigo João Pondé, que sofreu de um caso muito interessante de "mediunismo puro".

Aqui, houve fenômeno interessante, o único caso, neste livro, de mediunismo puro. Eu planejara escrever um conto de carro-de-bois com o carro, os bois, o guia e o carreiro. Penosamente, urdi o enredo, e, um sábado, fui dormir, contente, disposto a pôr em caderno, no domingo, a história (n. 1). Mas, no domingo caiu-me do ou no crânio, prontinha, espécie de Minerva, outra história (n. 2) também com carro, bois, carreiro e guia totalmente diferente da véspera. Não hesitei: escrevi-a, logo, e m'e esqueci da outra, da anterior. Em 1945, sofreu grandes retoques, mas nada recebeu da versão pré-histórica, que fôra definitivamente sacrificada (ROSA, 2016, p. 24).

Dessa maneira, a história lida em Sagarana é uma terceira história, totalmente diferente da original e semelhante a uma "entregue" a Rosa por vias que ele descreve como misteriosas, encantadas. Esse desdobramento é apresentado na estrutura do conto, podendo-se dizer que Rosa se mistura com o narrador, usando a máquina de escrita na 


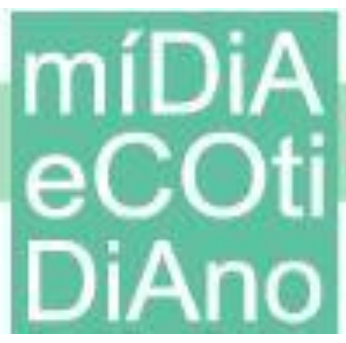

articulação de um agenciamento triplo, pelo qual se sobrepõem três formas narrativas: 1 . o caso na dimensão imaginária da fábula e do não-acontecido, em que a irara Risoleta testemunha uma viagem com duas figuras humanas e oito bois falantes. Nesse plano, a irara é capturada por Manuel Timborna e troca sua liberdade pela narração daquilo que testemunhou; 2. A transformação do relato animal em "caso-acontecido", recontado oralmente por Timborna ao narrador, para provar seu argumento de que os animais conversam entre si; e 3. o texto escrito, no qual lê-se o narrador "re-recontando" o que ouviu de modo diferente, enfeitado (SILVA, 2015). É uma sobreposição de camadas narrativas: a fantasia, a oralidade e a escrita literária, provocando também uma sobreposição de tempos e imagens.

Tal agenciamento nos remete aos escritos de Deleuze $(1985,1990)$ sobre a imagem cristal bergsoniana, que seria multifacetada, possível de ser visualizada por vários pontos de vista, fornecendo não uma verdade absoluta, mas diversos desdobramentos imagéticos. Assim, a imagem cristal estaria mais ligada à imagem-tempo cinematográfica, em que há uma subversão temporal, que por sua vez também embaralha não apenas passado, presente e futuro, como também as camadas da própria imagem, bem como da narrativa, que não se restringe mais a uma perspectiva linear. O pensamento de Deleuze, segundo Bellour (1999), nos mostra como tanto a literatura (a partir da imaginação) quanto a montagem influenciam o cinema, da mesma maneira como as possibilidades da linguagem cinematográfica, por sua vez, impactam nos tradicionais modelos narrativos, a exemplo da estrutura captada em "Conversa de bois".

A identificação de camadas narrativas e imagéticas indica o movimento de Rosa em captar temas do imaginário, da oralidade e da cultura popular para servir de ingrediente em sua mistura de alquimista. O que é evidenciado desde a epígrafe do conto, como reforça brevemente o texto de Bühler e Melo (2016). Desse modo, o coro extraído do canto do Boi-bumbá “-Lá vai! Lá vai! Lá vai!... / Queremos ver... Queremos ver... I - Lá vai o boi Cala-a-Boca / fazendo a terra tremer!...” traz, desde o elemento prétextual, a narrativa popular para dentro do caldeirão do feiticeiro. É um retorno que Rosa empreende em relação ao conceito de feitiçaria de Deleuze e Guattari, evidenciando a narrativa encantada dos antigos feiticeiros. 
Figura 2 - Epígrafe visual do conto "Conversa de bois"
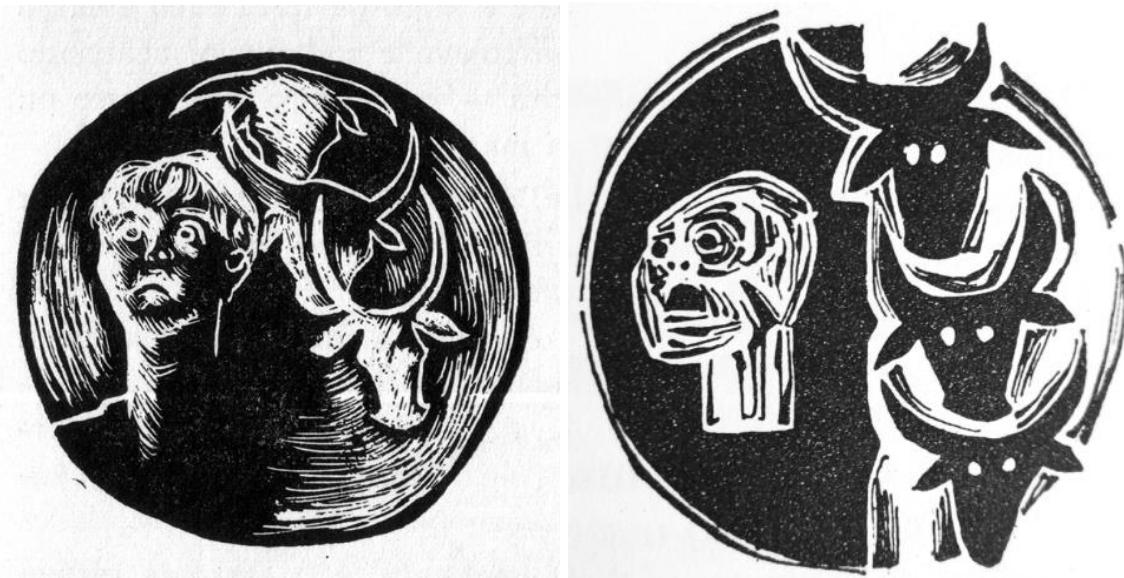

Fonte: ROSA, 1958; ROSA, 1977.

Nesse sentido, Bühler e Melo ressaltam a epígrafe como uma pista sobre a relevância dos bois enquanto chave para a compreender a história. Acompanhando a epígrafe escrita, há uma espécie de epígrafe visual: a imagem de uma cabeça humana com expressão de horror e um conjunto de três cabeças bovinas (Figura 2). Para Rowland (2011), além de uma indicação geral de leitura atribuída, entre outros elementos, às ilustrações e, sobretudo às epígrafes visuais em cada um dos contos de Sagarana, a construção material do livro parte de uma integração de diferentes elementos, tendo como direcionamento de sua arquitetura a escolha pela associação via metáforas. Segundo ela, há uma "estreita ligação entre ilustração e elementos paratextuais: toda a composição de Sagarana depende da articulação dessas duas dimensões para a configuração da unidade do livro" (ROWLAND, 2011, p. 159).

Corroborando com o que Rowland aponta, ainda, como uma síntese da dimensão metafísica de cada conto, ou um vislumbre do enredo, Nunes afirma que a ilustração inicial de "Conversa de bois" "invoca o insólito e o misterioso" (NUNES, 2015, p. 617). Tom místico que se soma a uma crítica ao racionalismo, como veremos mais a frente com Neves (2020). Nas duas versões, o contraste entre o branco e o preto (dia e noite, claro e escuridão), a boca humana formando um grito, as cabeças de homem e de boi soltas no espaço gráfico, são traços que evocam impressões e se ligam aos 


\section{míDiA

acontecimentos desenrolados no texto, sem deixar, no entanto, que o mistério que relaciona o menino e os bois, assim como imagem e palavra, seja totalmente apreendido - o que evidencia as lacunas que ilustrador e, principalmente, escritor articulam para que os leitores participem ativamente da busca de sentidos a partir, e entre, as duas linguagens, conforme apontam Nikolajeva e Scott sobre a dinâmica do livro ilustrado (2011).

Do mesmo modo que introduzem poeticamente e nos oferecem as coordenadas gerais da história, é a partir do emblema que abre o conto que formulamos as primeiras impressões sobre o texto, inferências que acabam por conduzir a uma segunda camada de pensamentos, de modo a explorar uma simbologia do boi e as suas possíveis relações com o texto e a temática do devir-animal que se aproxima.

\section{Simbologia de boi}

No conjunto da obra rosiana, a figura do boi ocupa lugar marcante. Pereira (2020) aponta o boi como uma das imagens narrativas que aproxima o homem da natureza, quase como um culto ao mítico que há nessa dimensão da existência humana e animal. Uma vez indicados pelas epígrafes textuais e visuais do feiticeiro como figuras-chave para interpretação do conto, os bois desempenham um papel central no decorrer da narração fabulosa de "Conversa de bois". Há, de início, a reivindicação da narrativa fantástica para justificar o falatório dos animais, quando o narrador diz em latim "Visa sub obscurum noctis pecudesque locutae. Infandum!" — "Visto no escuro da noite e falou o gado. Indescritível!" - para argumentar que não seria de hoje que os animais falassem entre si, sem que as pessoas queiram escutar. Para Bühler e Melo,

Em geral, no complexo imaginário das narrativas arcaicas, encontramos um conjunto de animais míticos (bestiário) que figuram no plano do combate exercendo tanto a função de antagonista (ferocidade) quanto a função de doador (ajudante mágico). Nessas narrativas o bestiário é trazido como parte de toda uma cenarização como montagem de uma geografia encantatória. Assim é que serpente, dragão, leão e cavalos alados constituem uma simbólica que povoam os contos populares (BÜHLER, MELO, 2016, p. 120).

Essas dimensões do bestiário nas narrativas literárias e oralidades são indicadas, também, no texto de Deleuze e Guattari, quando os autores classificam os animais em 


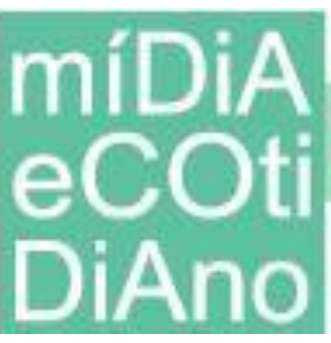

três espécies distintas. A primeira delas engloba os domésticos e familiares. Já os bois do conto, inicialmente, figuram na segunda categoria/espécie, sendo aproximados dos "animais com característica ou atributo, os animais de gênero, de classificação ou de Estado, tais como os grandes mitos divinos os tratam, para deles extrair séries ou estruturas, arquétipos ou modelos" (DELEUZE, GUATTARI, 1997, p. 18). Por hora, será explorada um pouco dessa classificação.

Figura 3 - Ilustrações de “Conversa de bois", versão de 1958 e 1977 respectivamente
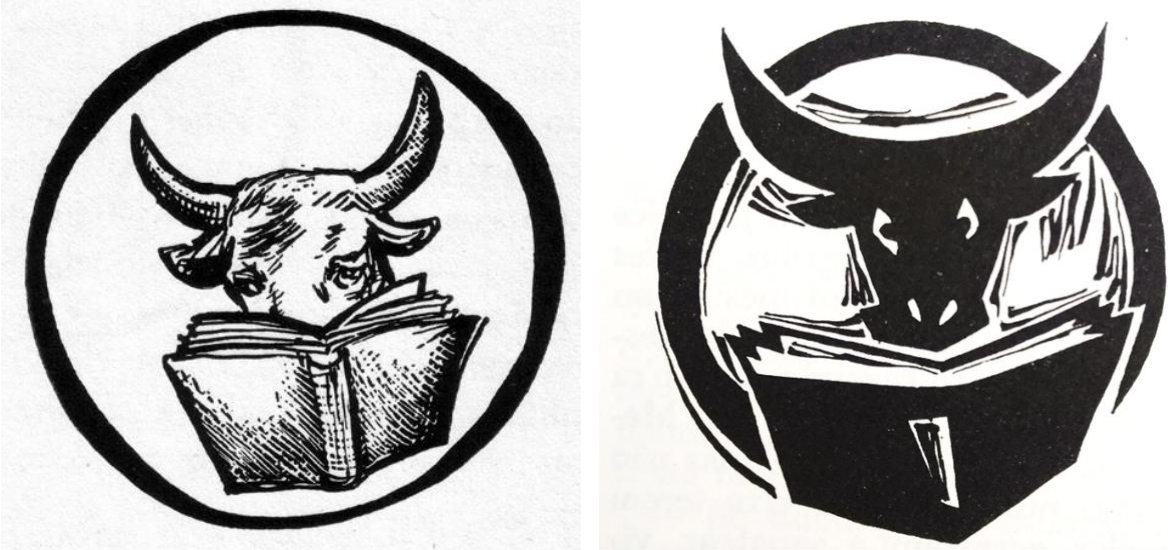

Fonte: ROSA, 1958; ROSA, 1977.

No Dicionário de símbolos a figura do boi é definida como um "símbolo de bondade, de calma, de força pacífica; de capacidade de trabalho e de sacrifício" (CHEVALIER, GHEERBRANT, 2019, p. 137). Os autores apresentam um resumo da simbólica mística dos bois, como figura que "marca a força e a potência, o poder de cavar sulcos intelectuais para receber as fecundas chuvas do céu, ao passo que os chifres simbolizam a força conservadora e invencível" (CHEVALIER, GHEERBRANT, 2019, p. 138). O livro faz a observação de uma certa mistura entre o imaginário de boi e touro. Segundo os autores, a imagem desse segundo conjura a ideia de força e de arrebatamento irresistível, de macho impetuoso. O touro é mais próximo da ferocidade. A simbologia do boi como animal de poder pacífico, calmo e contemplativo se revela adequada ao olhar-se para os diálogos no conto, quando, a certa altura, eles ponderam sobre como são diferentes dos animais que não trabalham com o homem e não pensam. "É bonito poder pensar, mas só nas coisas bonitas" (ROSA, 2016, p. 298). Assim, entende-se as várias 
ilustrações de bois ao longo do conto como um reforço visual dessa noção, uma vez que são mostrados em diversos ângulos, como figuras a serem contempladas e em aparente harmonia com a natureza e outros animais.

A ilustração do boi lendo um livro (Figura 3) reforça o caráter bondoso e intelectual-místico, mais uma vez com correspondência em diversos momentos da conversa dos animais, e até mesmo em seus silêncios: "Veio um silêncio. E todos, de olhos quase fechados, ficam vivendo na cabeça coisas mais fundas que o pensamento e o sonho, e, assim, sem pressa, chegam ao vau do ribeirão" (ROSA, 2016, p. 309). Além disso, Nunes (2015) sugere que a ilustração seja uma tradução gráfica da colaboração e proximidade que homem e bicho estabelecem no texto, como forma de fusão das duas figuras, lembrando, também, Pereira (2020). A imagem ultrapassa os significados presentes no conto para criar uma alegoria, inclusive, da experiência de leitura.

A curiosa figura do boi leitor aponta para cada um dos leitores que têm o livro em suas mãos; como apontamos antes, Rosa se referiu ao processo de escrita de Sagarana como um aboio dirigido a "um gado imenso" [...]. O boi, então, é o leitor - porque o leitor também "é boi": cada um dos leitores também é incluído em um contínuo existencial que engloba a natureza animal, como também vegetal e mineral (NUNES, 2015, p. 624-625).

O devir-animal é, portanto, entendido como uma das prerrogativas para a leitura e apreensão do conto e suas imagens, que servem de convite aos leitores para participação no jogo interpretativo tão característico da literatura rosiana que, nesse caso, é agenciado tanto no texto quanto pelas ilustrações. O homem, retomando o que disse Bellour sobre a literatura de Borges, é colocado em um espelho para estar ciente de si mesmo enquanto participante dessa dinâmica, que dele requer um desprendimento de si para tornar-se, também, animal - e, no caso, um boi.

A perspectiva formada por esse conjunto de símbolos acerca do boi é confrontada em dois momentos. O primeiro deles reside no paradigma em torno, também, de um boi. Abrindo mais uma camada narrativa de texto, o boi Brilhante lembra os outros sobre a tragédia de Rodapião, que é capturado pela racionalidade humana, diferenciandose dos demais. 
Figura 4 - Ilustrações de "Conversa de bois"
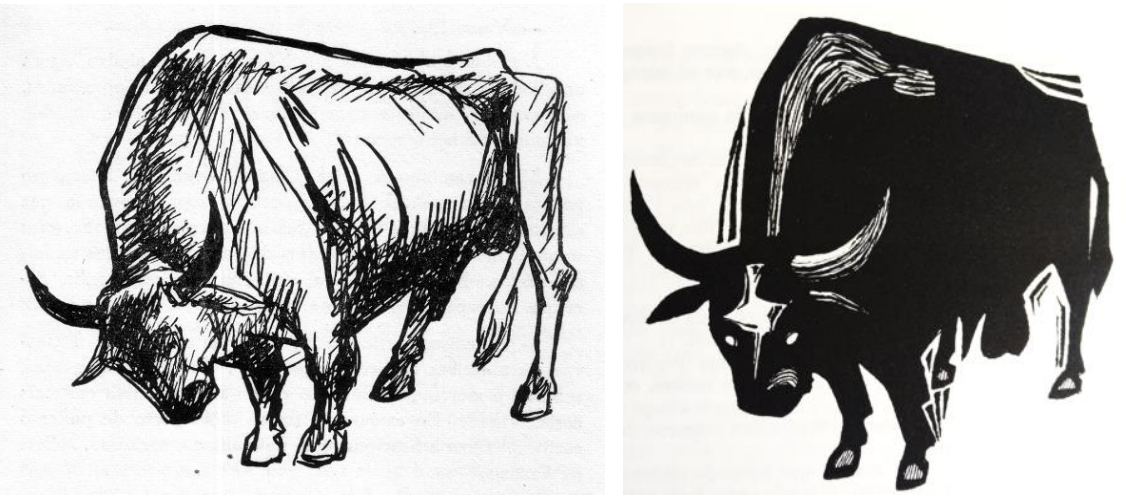

Fonte: ROSA, 1958; ROSA, 1977.

Figura 5 - Ilustração em "Conversa de bois"

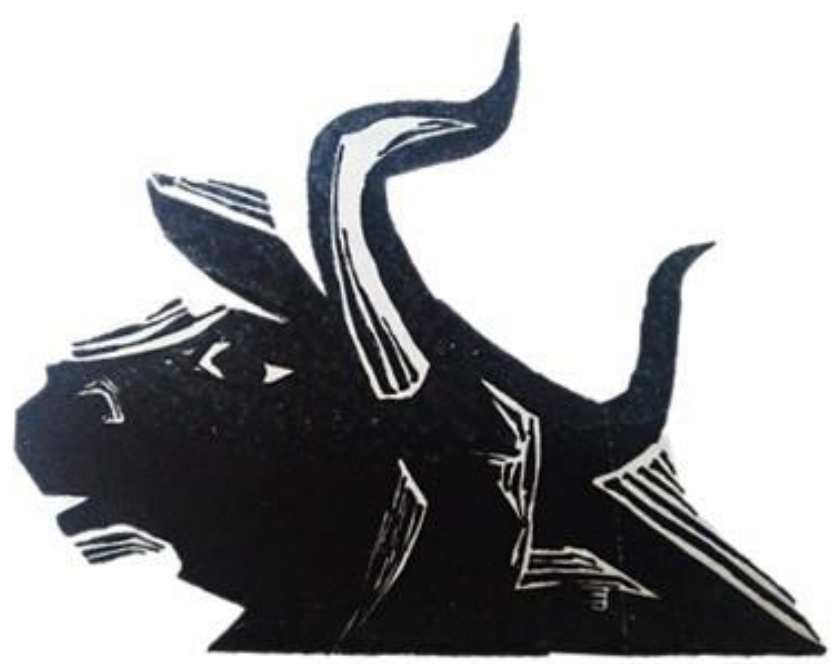

Fonte: ROSA, 1977.

No estudo sobre o devir-animal em "Conversa de bois", Neves (2020) relaciona a aproximação de Rodapião ao pensamento humano como uma crítica ao racionalismo cartesiano, reforçada com a constante necessidade dos demais bois em se diferenciar dos homens que, na visão dos bichos, incorporam a "fonte de todo o mal" (NEVES, 2020, p. 108). A aliança com o outro para além de si, ou seja, o humano, torna Rodapião menos contemplativo. É, segundo Silva (2015), além da apresentação da figura da "racionalidade", uma alegoria da luz, tornando Rodapião um "boi 'ilustrado" (Figura 4). 
A principal manifestação da sua contaminação é o andar de olhos abertos, atentos. Ele passou a pensar e "falou como homem" (ROSA, 2016, p. 314). Especificidade que é evidenciada pela ilustração de uma cabeça bovina de olhos e bocas bem abertas, em uma expressão quase humana (Figura 5). Ao contrário dos bois que caminhavam e conversavam de olhos fechados, Rodapião "espiava p'ra tudo, tudo queria ver... E nunca parava quieto" (ROSA, 2016, p. 304). E, no fim, sua ação em busca do caminho mais racional acaba por resultar em sua morte.

O segundo momento em que a perspectiva mística do boi é confrontada remete a um estado em que os bois da história saem do campo arquétipo, e parecem adentrar na fronteira da terceira definição de espécies animais: "Enfim, haveria animais mais demoníacos, de matilhas e afectos, e que fazem multiplicidade, devir, população" (DELEUZE, GUATTARI, 1997, p. 18). Aqui, as reverberações simbólicas de boi e touro se misturam. O conto passa a esquematizar um agenciamento que parte de uma proliferação animal, na qual vê-se uma multiplicidade atribuída aos bois. Multiplicidade essa que acaba por tomar o guia em um devir-animal, em um movimento de desterritorialização dos seus desejos a um campo de imanência em que podem se concretizar.

\section{Devir-boi para saciar o desejo}

Depois de Brilhante contar sua história sobre Rodapião e ponderar com os companheiros de viagem sobre os perigos de pensar como homem, o conto se desdobra mais uma vez para dar início a um novo agenciamento narrativo. Silva (2015) explica que a partir daí, armam-se as circunstâncias que desencadearão o fim da trama mágica. Desse modo, volta-se agora com mais atenção, assim como fazem os bois, às ações do "bezerrode-homem", o menino guia.

Ao longo do texto, são revelados fragmentos da história de Tiãozinho. O guia é um "pedaço de gente" que trabalha para o carreiro Agenor Soronho. Eles formam duas figuras opostas, dispostos até espacialmente em lugares diferentes, como é evidenciado pela estrutura maquínica do carro de boi - o homem em um extremo alto, em cima do carro, arrogante e imponente, e o menino no baixo, a pé, humilhado e fragilizado, acompanhando os animais (SILVA, 2015). 


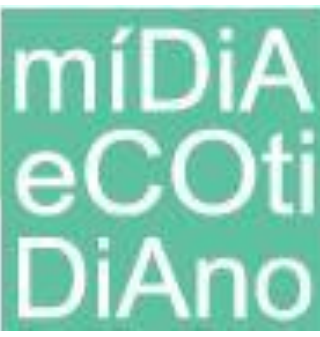

PPGMC

Assumindo o caráter narrativo que as imagens podem apresentar no livro ilustrado, Nunes (2015) chama atenção para o desenho em que uma cabeça de boi é posicionada frontalmente na página, com um carro de boi ao fundo (Figura 6). De acordo com Linden, em meio às funções estabelecidas entre texto e imagem, está a de colaboração, pela qual, "articulados, textos e imagens constroem um discurso único" (LINDEN, 2018, p. 121). Configuração essa que pode ser identificada, entre outras, na ilustração descrita, reforçando o entendimento de que "o carro é o sinal mais evidente da subjugação do animal pelo homem, que, no conto, é representado pelo carreiro Agenor Soronho, que maltrata tanto os animais [...] quanto o menino" (NUNES, 2015, p. 621). O contraste entre as duas imagens pode demonstrar, também, a oposição entre o pensamento humano e animal (razão e instinto), tão evidenciado nos diálogos entre os bois (NUNES, 2015).

Figura 6 - Ilustrações do conto "Conversa de bois"
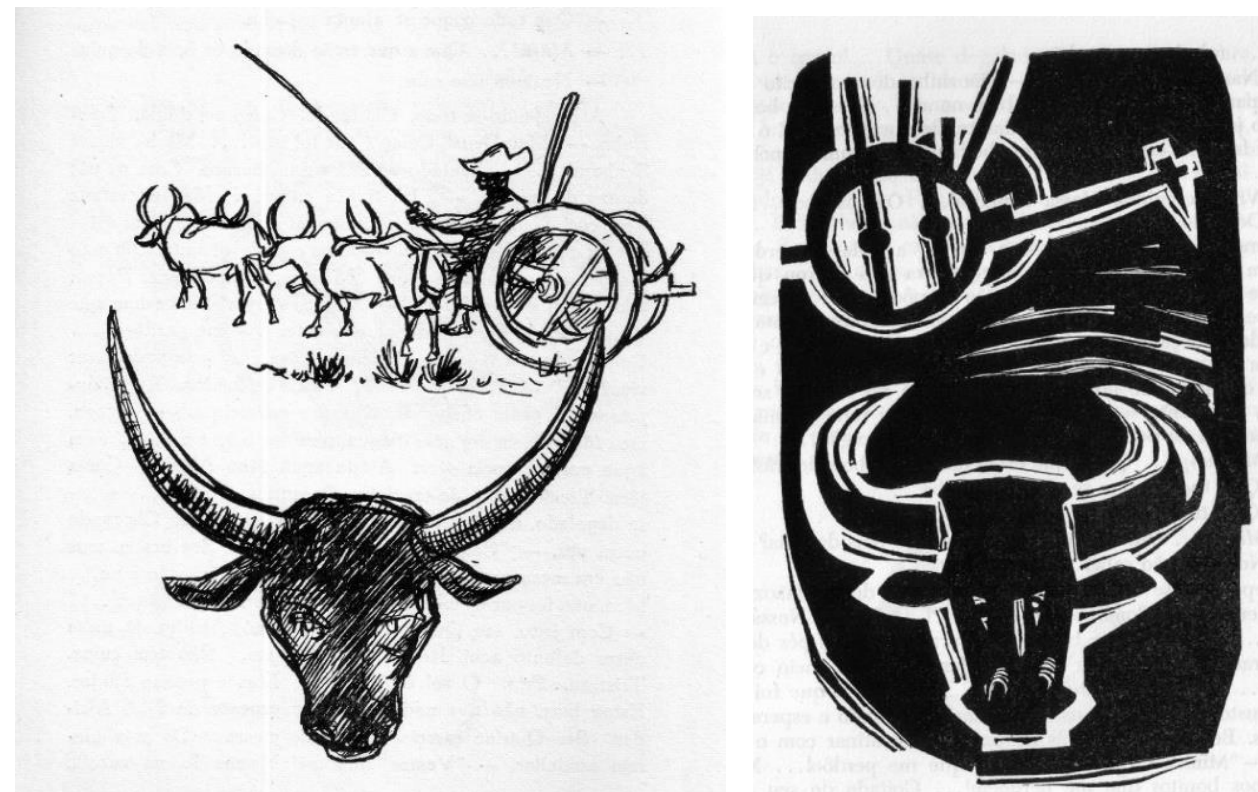

Fonte: ROSA, 1977; ROSA, 1958.

$\mathrm{Na}$ trama, o menino e o carreiro transportam rapaduras e um defunto. O morto é o pai de Tiãozinho, recém-falecido depois de muitos anos inválido e cego. O corpo está sendo levado para ser enterrado no cemitério do arraial. Mas além do luto, o "bezerro-dehomem" tem que suportar os maus tratos e os insultos constantes do carreiro. Um homem 


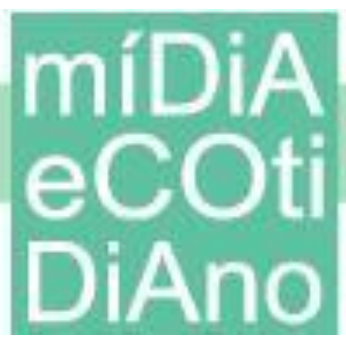

cruel, que, conforme sugere o conto, andava de carícias com a bela mãe de Tiãozinho mesmo antes da morte do pai. O que o deixava em fúria. Era esse homem quem sustentava a casa. E a morte do pai do menino parecia o alegrar.

Ao longo do relato, o narrador assume a perspectiva do guia em diversos momentos. Dessa maneira, o texto apresenta vislumbres dos desejos que tomam conta do pobre garoto, que, segundo os bois, "babou muita água dos olhos...” (ROSA, 2016, p. 319). Ao convocar novamente Deleuze e Guattari (1977), é possível entender que o que move esse novo agenciamento é o desejo de Tiãozinho. E os desejos do menino se modulam e intensificam na medida em que o ritmo da narrativa avança.

É Silva (2015) quem primeiro identifica as vontades crescentes que resultam no devir-animal do menino e, em seguida, traçam linhas de fuga destrutivas. Enquanto suporta calado e obediente as ordens e os desmandos do carreiro, os desejos do guia são expressos somente em pensamento, em estado latente. Primeiro, lê-se uma súplica indignada: "Mas Deus havia de castigar aquilo tudo." (ROSA, 2016, p. 303). Depois, os pensamentos de Tião evoluem para um desejo de vingança, com a promessa de que, quando grande, enfrentará o seu algoz: "Mas Tiãozinho espera... Há-de chegar o dia!... Quando crescer, quando ficar homem, vai ensinar ao seu Agenor Soronho... Ah, isso vai!... Há-de tirar desforra boa, que Deus é grande!” (ROSA, 2016, p. 304). Imerso em mais ressentimento e com as crescentes ofensas do carreiro, o menino passa a manifestar um desejo de morte: "Por que é que não foi seu Agenor Carreiro quem a morte veio buscar?! Havia de ter sido tão bom!...” (ROSA, 2016, p. 310). Até que o ódio toma conta dos pensamentos do menino que revela, enfim, o seu desejo homicida: "Enlameado até a cintura, Tiãozinho cresce de ódio. Se pudesse matar o carreiro... Deixa eu crescer!... Deixa eu ficar Grande!... Hei de dar conta desse danisco..." (ROSA, 2016, p. 311).

É na armação do novo agenciamento narrativo e na mudança de velocidade no ritmo do conto que os desejos do menino são potencializados e buscam uma forma de sair do plano mental. A noite chega e as personagens parecem emergir em uma camada de suspensão, inicialmente mais lenta. Um estado de sonolência toma conta das personagens humanas, e a partir daí o texto descreve os bois percebendo que Tião dorme enquanto caminha à frente deles. Esse estado transporta o menino para mais perto de um ser-boi, assimilando a habilidade destes em caminhar dormindo. 
Todas as camadas narrativas traçadas até agora convergem para uma mesma linha, aproximando o menino de um devir, que é, em síntese, um estado de entre, é explorado rapidamente a ideia de "meio", de "não-lugar" ou "entre" recorrente na literatura rosiana. "Mesmo meio no sono está Tiãozinho. Mais de meio: tão só uma pequena porção dele vigie, talvez, O resto flutua em lugares estranhos. Em outra parte..." (ROSA, 2016, p. 319, grifo nosso). Flutuando nesse novo estado, dentro da escuridão mística da noite, o fluxo de pensamentos de Tiãozinho começa a se misturar com os pensamentos e as vozes dos bois. Vê-se, então, o devir-animal se formando, quando Deleuze e Guattari diriam que se passa a vislumbrar, então, "uma matilha, um bando, uma população, um povoamento, em suma, com uma multiplicidade" (DELEUZE, GUATTARI, 1997, p. 16). O guia começa a se misturar com cada boi, um por um, até que eles passam a formar bloco:

- Mhú! Hmoung!... Boi... Bezerro-de-homem... Mas, eu sou o boi Capitão!... Moung!... Não há nenhum boi Capitão... Mas, todos os bois... Não há bezerro-de-homem!... Todos... Tudo... Tudo enorme... Eu sou enorme!... Sou grande e forte... Mais do que seu Agenor Soronho! ... Posso vingar meu pai... Meu pai era bom. Ele está morto dentro do carro... Seu Agenor Soronho o diabo grande... Bate em todos os meninos do mundo... Mas eu sou enorme... Hmou! Hung!... Mas, não há Tiãozinho! Sou aquele-que-tem-um-anel-branco-aoredor- dasventas!... Não, não, sou o bezerro-de-homem!... Sou maior do que todos os bois e homens juntos (ROSA, 2016, p. 320).

O devir-animal do menino ativa os afetos dos bois, que "se tornam companheiros de infortúnio e cúmplices no desejo de vingança e na morte do Agenor Soronho, que os explorava e maltratava violentamente" (NEVES, 2020, p. 109). Nos deparamos agora com um boi que foge da sua simbologia mística de bondade para entrar em uma dimensão demoníaca, múltipla, mais próxima do touro. Assim, os bois detonam suas potencialidades e todos eles juntos (bois e menino) passam a tramar a morte de Soronho, ao passo em que também reafirmam a sua força e a sua multiplicidade enquanto matilha. Em disposições deleuzianas, eles assumem uma multiplicidade de termos heterogêneos e "de co-funcionamento de contágio, entram em certos agenciamentos e é neles que o homem opera seus devires-animais" (DELEUZE, GUATTARI, 1997, p. 19). 
Figura 7 - Ilustrações de capa e de miolo referentes ao conto "Conversa de bois"
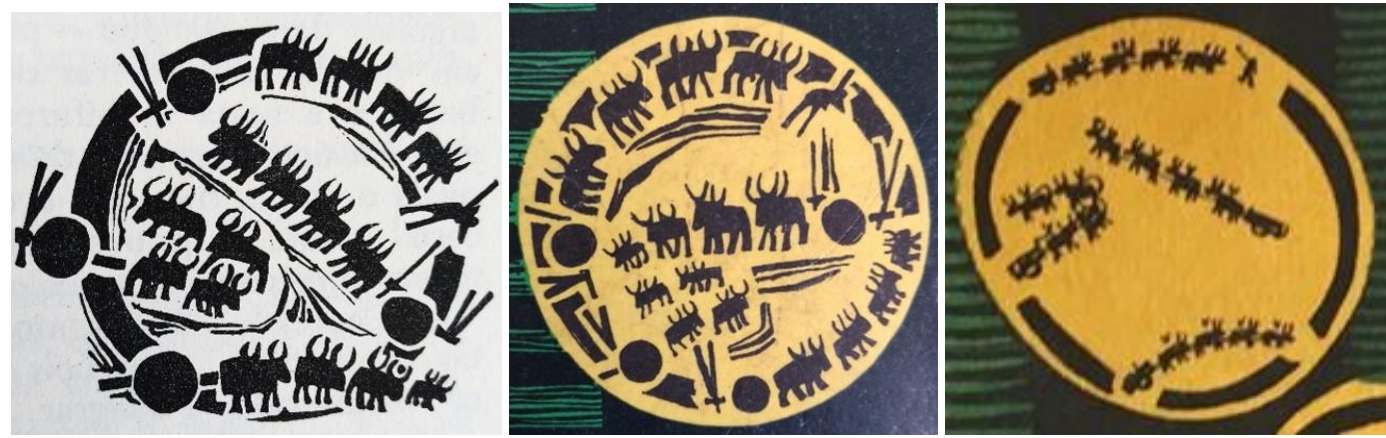

Fonte: ROSA, 1977; ROSA, 1958.

A multiplicidade descrita transborda das imagens textuais para as imagens gráficas por meio das ilustrações. A metáfora é o recurso responsável por pontuar uma correspondência visual dessa proliferação, ou do que chamaremos de "boiferação", no emblema escolhido por Guimarães Rosa para representar o conto na capa de Sagarana. A mesma ilustração é vista no miolo do livro, acompanhando o texto a que se refere. Mesmo com as variações de estilo que o desenho sofreu ao longo das reimpressões, é interessante observar como a escolha dos traços reverbera esse momento de devir-boi. Há uma multiplicidade de bois conduzindo o carro. Bois que vão para diversas direções e, em alguns momentos, extrapolam a linha — ou a fronteira - que delimita o espaço gráfico do desenho. Uma escolha curiosa, se levar em conta tanto os conceitos trabalhados até agora quanto o desencadeamento de uma linha de fuga que gera morte na trama.

Na continuação do conto, a máquina de desejo é, então, ativada e o devir-boi do menino resulta em uma linha que escapa para a aniquilação. "Exatamente por causa do "perigo" próprio a toda linha que escapa, a toda linha de fuga ou de desterritorialização criadora: virar destruição, abolição" (DELEUZE, GUATTARI, 1997, p. 87). Em um movimento praticamente ensaiado, o menino grita, despertando de seu estado de sonolência, e os bois se projetam para frente todos de uma vez só. É o fim de Agenor Soronho.

Com Tiãozinho desperto de seu devir-boi e horrorizado com a concretização de seus desejos, há um retorno para as imagens de abertura, que servem de epígrafe visual 


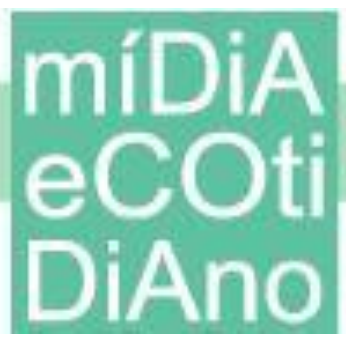

do conto. As cabeças de boi e o rosto horrorizado do menino, desde o início indicavam o desfecho da narrativa textual, agindo como os traços que anteciparam as palavras, em um devir-ilustra-palavra. Após o desvelamento, o conto entra em um novo ritmo. Mais rápido. Mais confuso. Tião chora com os pés dentro de um buraco. Buracos dos quais ele desviava enquanto fazia bloco com os bois. Chegam dois cavaleiros. Os cavaleiros se assustam. O menino em desespero. Percebem que o carreiro foi decapitado pela roda do carro de boi. Os homens ajudam. O guia segue viagem, agora com dois defuntos. O carro parece contente. E os bois? Os da frente, ninguém sabe o que dizem. Os de trás, ponderam: "Que tudo o que se ajunta espalha". O que significa? Toada triunfal.

\section{Considerações Finais}

Diferentemente da grande maioria dos estudos rosianos, e até de pesquisas que pensam o devir no mesmo conto estudado nessas páginas, as imagens (mentais e visíveis) revelaram-se dispositivos ricos para desenvolver as reflexões e apreensões apresentadas. O que representa uma boa contribuição para o estado da arte do autor, realizando, com respeito às palavras que são tão caras a Rosa, um movimento de virada pictórica, que, conforme Mitchell (2015), buscou compreender as questões relacionadas à animalidade da narrativa, também, pelo ponto de vista do que as próprias imagens poderiam nos dizer.

As simbologias de boi desencadearam uma reflexão sobre um Rosa imerso no que Deleuze e Guattari chamaram de devir. O aparente devir-animal do escritor, nosso feiticeiro, o fez "receber" a história agenciada em diversas camadas narrativas e imagéticas, de modo a construir um relato fabuloso, híbrido como uma imagem-cristal bergsoniana, nos lembrando que as fronteiras entre diferentes linguagens podem ser contaminadas e reorganizadas, possibilitando o uso de conceitos dos diferentes campos, como o do cinema, para tratar das configurações imagéticas no texto.

De forma mágica, segundo as palavras de Bellour, a alquimia empreendida por Rosa e explorada aqui consiste em mesclar elementos diversos de maneira a construir diferentes dimensões interpretativas de texto, imagem e livro - enquanto objeto (Krauss) ou artefato (Rowland). Uma vez associadas para formar um objeto de arte, ilustração e palavra são combinadas, ora em complementaridade ora em simetria, de modo a reafirmar 


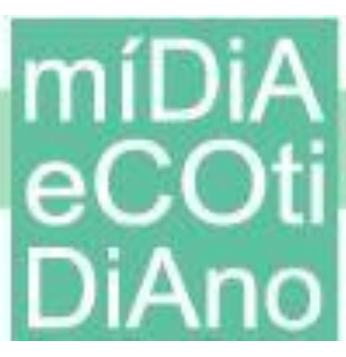

a força autoral de Rosa, assumindo, dessa maneira, o caráter metafísico tão característico de sua literatura.

Em "Conversa de bois", a ilustração exerce o poder latente de nos capturar em um devir-palavra. Ela mesma é um devir-palavra quando se veste como metáfora e reverbera aspectos invisíveis e indizíveis do texto, mostrando que a imagem pode entrar em diálogo com outras linguagens sem deixar, ela mesma, de criar realidades e significados próprios, independentes, conforme discorremos a partir do comentário de Mitchell. Dessa maneira, temas centrais em toda literatura rosiana como razão x instinto, luz x escuridão, bem x mal puderam ser encontrados também nos traços, com as devidas particularidades que essa forma de pensamento desenvolve.

Escolheu-se aqui dar voz a algumas das multiplicidades apreendidas com a leitura do conto. E, assim, observou-se a riqueza que a narrativa em devir nos apresenta. A possibilidade infinita de desterritorialização, de criação de linhas de fugas e novas associações. E, vale reforçar, a "matéria vertente" de Rosa é também devir.

\section{Referências}

BELLOUR, R. L'entre-images: photo, cinéma, vidéo. Différence, 1990.

. L'entre-images 2: mots, images. POL Editeur, 1999.

BERGSON, H. A evolução criadora. São Paulo: Ed.UNES, 2010

BÜHLER, A. M. C.; MELO, J. F. de. A contação dos bois: uma leitura sobre as vozes bovinas no conto "Conversa de bois", na obra Sagarana. Revista Estação Literária. Londrina, volume 17, p. 114-134, jul. 2016.

CHEVALIER. J.; GHEERBRANT, A. Dicionário de símbolos: mitos, sonhos, costumes, gestos, formas, figuras, cores, números. Rio de Janeiro: José Olimpo, 2019.

DELEUZE, G. Cinema, a imagem-movimento. São Paulo: Brasiliense, 1985.

A imagem-Tempo. São Paulo: Brasiliense, 1990.

DELEUZE, G.; GUATTARI, F. Mil platôs: capitalismo e esquizofrenia. vol. 1. Trad. Aurélio Guerra Neto e Célia Pinto Costa. Rio de Janeiro: Editora 34, 1995.

Editora 34, 1997.

Mil platôs: capitalismo e esquizofrenia. vol. 4. Trad. Suely Rolnik. São Paulo:

Kafka: por uma literatura menor. Rio de Janeiro: Imago Editora, 1977. 
KRAUSS, R. A escultura no campo ampliado. Rio de Janeiro: Gávea, 1984. 2014.

LINDEN, S. V. der. Para ler o livro ilustrado. São Paulo: SESI-SP, 2018.

LORENZ, G. Diálogo com Guimarães Rosa. In: ROSA, João Guimarães. Ficção completa. vol. 1. Rio de Janeiro: Nova Aguilar, 1994.

NEVES, M. S. Um olhar sobre a ficção animalista de João Guimarães Rosa: devires e metamorfoses. Caligrama: Revista de Estudos Românicos, v. 25, n. 2, p. 99-115, 2020.

MITCHELL, W. T. J. O que as imagens realmente querem? In: ALLOA, E. Pensar a imagem. Belo Horizonte: Autêntica Editora, 2015, pp. 165 - 189.

NIKOLAJEVA, M.; SCOTT, C. Livro ilustrado: palavras e imagens. São Paulo: Cosac Naify, 2011.

NUNES, F. V. A ilustração literária de Poty. 2015. 2 v. 709 f. Tese (Doutorado) - Setor de Ciências Humanas, Programa de Pós-Graduação em Letras, Universidade Federal do Paraná. Curitiba, 2015.

PEREIRA, I. M. O universo zooliterário-poético rosiano. 2020. 195 f. Tese (Doutorado) Programa de Pós-Graduação em Estudos Literários, Universidade Federal de Uberlândia. Uberlândia, 2020.

RÓNAI, P. Rondando os segredos de Guimarães Rosa. 1956. In ROSA, João Guimarães. Manuelzão e Miguilim (Corpo de baile). Rio de Janeiro: Nova Fronteira, 2016.

ROSA, J. G. Manuelzão e Miguilim ("Corpo de baile"). 5. ed. Rio de Janeiro: Editora José Olympio, 1972.

Sagarana. Ed. Especial. Rio de Janeiro: Nova Fronteira, 2016.

Sagarana. Rio de Janeiro: Livraria José Olympio Editora, 1977.

Sagarana. Rio de Janeiro: Livraria José Olympio Editora, 1958.

Cidades, 1975

Sagarana emotiva: cartas de J. Guimarães Rosa a Paulo Dantas. São Paulo: Duas

ROWLAND, C. A forma do meio: livro e narração na obra de João Guimarães Rosa. São Paulo: Editora Unicamp, 2011.

SILVA, C. R. da. Procedimentos narrativos em "Conversa de bois". Fólio - Revista de Letras. Vitória da Conquista, v. 7. n. 1. p. 47-66, jan./jun. 2015. 